\title{
Sprawozdanie z konferencji naukowej pt. Życie codzienne żołnierzy na przestrzeni dziejów. Wojsko w drodze Łódź, 1 czerwca 2017 r.
}

W dniu 1 czerwca 2017 r. w Instytucie Historii Wydziału Filozoficzno-Historycznego Uniwersytetu Łódzkiego odbyła się konferencja naukowa Życie codzienne żołnierzy na przestrzeni dziejów. Wojsko w drodze. Spotkanie otworzyła prodziekan Wydziału Filozoficzno-Historycznego ds. nauki, prof. dr hab. Anna Marciniak-Kajzer. Podkreśliła interdyscyplinarność konferencji oraz życzyła owocnych obrad. Natomiast Dyrektor Instytutu Historii, prof. Dariusz Jeziorny, będacy kolejnym mówca, zwrócił uwagę na znaczenie podejmowania problematyki wojskowej. Zebranych powitał także przewodniczacy komitetu organizacyjnego, dr hab. prof. UŁ Jarosław Kita.

Konferencja zgromadziła w Łodzi 13 prelegentów $z$ siedmiu ośrodków akademickich (Uniwersytet Łódzki, Katolicki Uniwersytet Lubelski, Uniwersytet Kardynała Stefana Wyszyńskiego w Warszawie, Uniwersytet Jana Kochanowskiego w Kielcach - Filia w Piotrkowie Trybunalskim, Akademia Sztuki Wojennej, Akademia im. Jana Długosza w Częstochowie, Akademia Pomorska w Słupsku).

Celem konferencji było pochylenie się nad rzadko do tej pory podejmowana problematyka translokacji wojsk na przestrzeni wieków. Stąd referaty podejmowały m.in. takie zagadnienia, jak organizacja przemarszów, pokonywanie przeszkód terenowych, środki transportowe, a także zaplecze logistyczne. Organizatorzy zdecydowali się na wyodrębnienie trzech części, w ramach których referaty ułożone zostały zgodnie z kluczem chronologiczno-problemowym.

Pierwszą część obrad rozpoczął dr Kirił Marinow, który wygłosił referat pt. Przez wawozy i lasy. Armia bizantyńska wobec trudnodostepnych obszarów w świetle IX konstytucji Taktyk Leona VI 
Mądrego. W swoim wystąpieniu prelegent przybliżył zalecenia cesarskie dla armii bizantyjskiej, dotyczące pokonywania obszarów charakteryzujących się trudną rzeźbą terenu, głównie wąwozów górskich i terenów zalesionych. Następnie referat pt. $Z$ kasztelu do obozu wojennego. Konno, zbrojnie iz dobrze zaopatrzonym wozem wygłosił prof. dr hab. Jan Szymczak, który opowiedział o przygotowaniach i wyposażeniu rycerza do wyprawy wojennej, m.in. środkach transportu (konie, wozy), żywności, noclegach. Wystąienie dopełniała prezentacja zawierajacca ilustracje. $Z$ kolei dr hab. Tadeusz Grabarczyk zaproponował skupienie się na pokonywaniu przeszkód wodnych przez średniowieczne armie („Sucha stopa” czy "skaczac $w$ fale”. Przekraczanie rzek przez wojska polskie od XI do poczatku XVI $w$.). Na wybranych przykładach referent pokazał trudności, jakie stawały przed armiami w średniowieczu, tj. szerokość i głębokość rzeki, konieczność budowania mostów, warunki atmosferyczne. Pierwszą część zamykał referat dr. hab. Andrzeja Niewińskiego (Droga do wojny. Przygotowania militarne w wybranych źródłach średniowiecznych), poruszający kwestie związane $z$ przygotowaniami do działań wojennych. Analiza przebiegała śladem informacji zawartych w źródłach średniowiecznych.

Część druga obrad rozpoczęła się od wypowiedzi dr. hab. Aleksandra Bołdyrewa dotyczacej znaczenia sprzetu taborowego dla wojsk polskich w dobie panowania ostatnich Jagiellonów (Sprzęt taborowy $w$ przemieszczeniu armii zaciężnej $w$ Polsce ostatnich Jagiellonów). Prelegent odnosił się do sprzętu, jaki armia musiała posiadać na wyprawę (wozy), jak i do jego wytwórców. Magister Jędrzej Kałużny poruszył w swoim wystappieniu problem miejskich wozów bojowych z ziem łęczyckiej i sieradzkiej, które weszły w skład armii Królestwa Polskiego (Miejskie wozy bojowe $w$ składzie armii Królestwa Polskiego $w$ XVI-XVII $w$.). Natomiast dr Zbigniew Hundert pokusił się o przedstawienie roli strażników koronnego i wojskowego dla armii, ukazanie kryteriów obsady tych stanowisk, wynikajacych zarówno $z$ potrzeb natury wojskowej, jak i politycznej (Strażnicy koronny i wojskowy w dobie Jana Sobieskiego. Osoby odpowiedzialne za organizowanie przemarszów armii koronnej). Kolejny referent, dr hab. prof. UŁ Jarosław Kita skoncentrował się na analizie wyzwań związanych $z$ przemieszczaniem się, jakie stanęły przed powstańcami w czasie styczniowego zrywu narodowowyzwoleńczego. Zwracał uwagę na brak zaplecza logistycznego dla oddziałów powstańczych oraz warunki aprowizacyjne i higieniczne 
oddziałów powstańczych (Przemieszczanie się partii powstańczych podczas powstania styczniowego).

Na część trzecią składało się pięć referatów. Ppłk dr Jacek Lasota, również na podstawie własnych doświadczeń, pokazał, jak pokonuje się przeszkody wodne $z$ użyciem czołgów (Pokonanie przeszkody wodnej pod woda przez pododdziały czołgów - teoria i praktyka). Całość wystapienia bogato ilustrowana była zdjęciami oraz uzupełniana licznymi anegdotami. Kolejny prelegent, dr hab. prof. AJD Robert Majzner skoncentrował się na analizie spostrzeżeń i ukazaniu wniosków, jakie wynikały $z$ raportów Oddziału II Sztabu Głównego Wojska Polskiego dotyczących wydarzeń w Abisynii i wojny domowej w Hiszpanii, dla polskich sił zbrojnych w aspekcie ewolucji sztuki wojennej (Abisyńskie $i$ hiszpańskie obserwacje Oddziału II SGWP $w$ zakresie mobilności oraz zaopatrywania armii na polu walki 1935-1939). Następny referent, dr hab. prof. UŁ Witold Jarno zaprezentował służbę samochodowa Wojska Polskiego i jej zadania tuż przed wybuchem II wojny światowej. Natomiast dr Marek Brylew omówił znaczenie oddziału gospodarczego dla kontyngentów wojskowych realizujacych zadania poza Polska (Rola i zadania oddziału gospodarczego w zabezpieczeniu materiałowym Polskich Kontyngentów Wojskowych realizujacych zadania poza granicami kraju). Koncepcje i plany przeprawy przez Kanał Sueski w przeddzień czwartej wojny arabsko-izraelskiej z października 1973 r. stały się przedmiotem rozważań dr Magdaleny Pogońskiej-Pol (Kanał do zdobycia - egipskie założenia przeprawy przez Kanał Sueski w przededniu wojny październikowej 1973 r.).

Różnorodność podjętej problematyki oraz charakter wystapień skłoniły przybyłych na konferencję pracowników, jak i studentów Instytutu Historii UŁ, do ożywionej dyskusji. Czas przewidziany na dyskusję po każdej części okazał się niewystarczający.

Podsumowując obrady, dr hab. prof. UŁ Jarosław Kita stwierdził, że konferencja bez wątpienia spełniła swój cel - dla uczestników stała się bowiem forum wymiany poglądów na temat przemieszczania się armii na przestrzeni dziejów. Obrady zamkną dr hab. prof. UŁ Dariusz Jeziorny, zapraszając jednocześnie na kolejną konferencję.

Magdalena PogońsKa-Pol UNIWERSYTET ŁÓDZKI"

* Wydział Filozoficzno-Historyczny, Instytut Historii, Katedra Historii Polski i Świata po 1945 r., e-mail: mpogon@op.pl; mpogonskapol@uni.lodz.pl. 